Article

\title{
The Role of Organic Matter in the Formation of High-Grade Al Deposits of the Dopolan Karst Type Bauxite, Iran: Mineralogy, Geochemistry, and Sulfur Isotope Data
}

\author{
Somayeh Salamab Ellahi, Batoul Taghipour * and Mostafa Nejadhadad \\ Department of Earth Sciences, Shiraz University, Shiraz 71454, Iran; somayesalamat@yahoo.com (S.S.E.); \\ mostafanejadhadad@yahoo.com (M.N.) \\ * Correspondence: taghipour@shirazu.ac.ir; Tel.: +98-713-613-7457
}

Academic Editor: Pablo Cubillas

Received: 23 March 2017; Accepted: 31 May 2017; Published: 12 June 2017

\begin{abstract}
Mineralogical and geochemical analyses of the Dopolan karstic bauxite ore were performed to identify the characteristics of four bauxite horizons, which comprise from top to bottom, bauxitic kaolinite, diaspore-rich bauxite, clay-rich bauxite, and pyrite-rich bauxite. Diaspore, kaolinite, and pyrite are the main minerals; böhmite, muscovite, rutile, and anatase are the accessory minerals. The main minerals of the Dopolan bauxite deposit indicate slightly acidic to alkaline reducing conditions during bauxitization. Immobile elements ( $\mathrm{Nb}, \mathrm{Ta}, \mathrm{Zr}, \mathrm{Hf}$, and rare earth elements) are enriched in the diaspore-rich horizon, which also has the highest alumina content, whereas redox sensitive elements (e.g., $\mathrm{Cr}, \mathrm{Cu}, \mathrm{Ni}, \mathrm{Pb}, \mathrm{Zn}, \mathrm{Ag}, \mathrm{U}$, and $\mathrm{V}$ ) are enriched in the lowest horizon of pyrite-rich bauxite. The presence of a high content of organic matter was identified in different horizons of bauxitic ore from wet chemistry. The presence of organic matter favored Fe bioleaching, which resulted in $\mathrm{Al}$ enrichment and the formation of diaspore-rich bauxite. The leached $\mathrm{Fe}^{2+}$ reacted with the hydrogen sulfur that was produced due to bacterial metabolism, resulting in the formation of the pyrite-rich horizon towards the bottom of the Dopolan bauxite horizons. Biogeochemical activity in the Dopolan bauxitic ore was deduced from the reducing environment of bauxitization, and the deposition of framboidal and cubic or cubic/octahedral pyrite crystals, with large negative values of $\delta^{34} S$ of pyrite $(-10 \%$ to $-34 \% 0)$ and preserved fossil cells of microorganisms.
\end{abstract}

Keywords: organic matter; pyrite; $\mathrm{Al}$ enrichment; sulfur isotope; Dopolan bauxite

\section{Introduction}

Previous studies have demonstrated that differences in the mineralogical compositions of bauxite horizons could be related to different $\mathrm{Eh}$ and $\mathrm{pH}$ of the depositional environment as a result of organic matter variations in the original host rocks [1-6]. In the presence of a high content of organic matter, microorganisms, such as bacteria and fungi, convert metal compounds into their water-soluble forms. These water-soluble metals are biocatalytic productions of this leaching process [7]. Microorganisms are able to mobilize metals by (1) the formation of organic and inorganic acids, (2) oxidation and reduction reactions, and (3) the excretion of complexing agents [8-12]. Bacterial activity has an important role in the leaching of iron to alter a high-iron, low-grade red bauxite ore to a high-grade, gray alumina ore with low Fe content $[2,3,13]$.

The bauxite deposits of the Zagros orogenic belts in southwestern Iran were deposited during two periods: (1) in karst cavities at the boundary between the Sarvak and Ilam Formations (Cretaceous bauxite deposits), such as the Mandan, Dehnow, and Sarfaryab deposits, and (2) deposited at the boundary between the Neyriz and Khaneh-Kat Formations (Triassic bauxite deposits), such as the 
Dopolan deposit. Most of Iranian karst bauxites in the Zagros orogenic belts are low-grade, böhmitic, diasporic bauxites [14-17]. They contain 20-45 wt $\% \mathrm{Al}_{2} \mathrm{O}_{3}, 3-38$ wt $\% \mathrm{Fe}_{2} \mathrm{O}_{3}$, and in most cases appear red in outcrops. Contrastingly, the Dopolan bauxite has exceptionally high $\mathrm{Al}_{2} \mathrm{O}_{3}(62-78 \mathrm{wt} \%$, average $65 \mathrm{wt} \%)$, low total $\mathrm{Fe}(0.56-32 \mathrm{wt} \%$, average $5 \mathrm{wt} \%)$, and is almost gray in the field [18]. The Dopolan bauxite deposit has been in production for more than 40 years. Mineralization includes three separated pocket and tabular orebodies (Shahid Nilchian, Dorag, and $\mathrm{C}$ mine). The ore reserves total 8 to 15 million metric tonnes of $47 \mathrm{wt} \% \mathrm{Al}_{2} \mathrm{O}_{3}$ [19].

A previous study of the Dopolan bauxite described mineralogical and geochemical characteristics of the bauxitic horizons [18]. Salamab [18] suggests that the bauxite formed as a continental deposit filling karstic cavities at the boundary of the Khaneh-Kat and Neyriz formations. The present study is focused on the organic matter rich bauxite horizons, which are characterized by an association with the abundance of pyrite. We investigated the role of organic matter and microorganisms in the mobility of trace elements, mobilization and deposition of iron, and $\mathrm{Al}$ enrichment in the bauxite profile. To attain these goals, the ore composition (major, trace, and rare earth elements), the organic matter content, and the sulfur isotopic values of pyrite of a series of bauxite horizons were analyzed using optical microscopy, scanning electron microscopy (SEM), X-ray diffractometry (XRD), and inductively coupled plasma mass spectrometry (ICP-MS).

\section{Geology}

The Dopolan bauxite deposit is located $110 \mathrm{~km}$ northwest of Share-Kord city, southwestern Iran (Figure 1a) [18]. The deposit is situated in the high Zagros Mountains and developed in the Triassic carbonates of the Khaneh-Kat Formation in the contact zone with the Jurassic carbonates of the Neyriz Formation. The Zagros orogenic belt extends for approximately $1500 \mathrm{~km}$ from Kermanshah in the northwest of Iran to Bandar Abbas in the south of the country. The Zagros zone is located in the boundary between the Arabian and Eurasian lithospheric plates. It was formed during the Cenozoic orogenic movements as a result of collision between the Arabian and Eurasian plates [20,21]. This collision created numerous folds and thrusts that now appear as large linear anticlines. Outcrops of the bauxitic horizons occur in a large structure called the Sabzkuh-Kelar anticlinorium, which is bounded by two thrust faults. The Sabzkuh anticline is $65 \mathrm{~km}$ long. In the studied area, the Zagros stratigraphy consists of Cambrian to Quaternary sequences. The youngest strata are located on limbs and the oldest rocks are in the core of the anticlinorium (Figure 1b). The Dalan Formation is the oldest exposed rock unit in the core of the Sabzkuh anticline. The Dopolan bauxite deposit is hosted within Triassic carbonate rocks of the Khaneh-Kat Formation. The Khaneh-Kat Formation includes dolostones, dolomitic limestones, marly limestones with interbedded marl, and argillaceous limestones overlying Permian pink dolostones of the Dalan Formation. The Dopolan bauxite deposit is stratabound and crops out in an erosional window. The boundary between the Khaneh-Kat Formation and the overlying Jurassic limestone and shaly limestone of the Neyriz Formation is an erosional unconformity that contains the Dopolan bauxite horizon. On its turn, the Neyriz formation is covered by a sequence comprising, from older to younger: the Surmeh, the Sarvak, and the Gurpi Formations [19]. Karstified features within the Khaneh-Kat Formation are infilled by bauxite. The layers of bauxite vary from 1 to $8 \mathrm{~m}$ in thickness and can be more than $1000 \mathrm{~m}$ in length. 


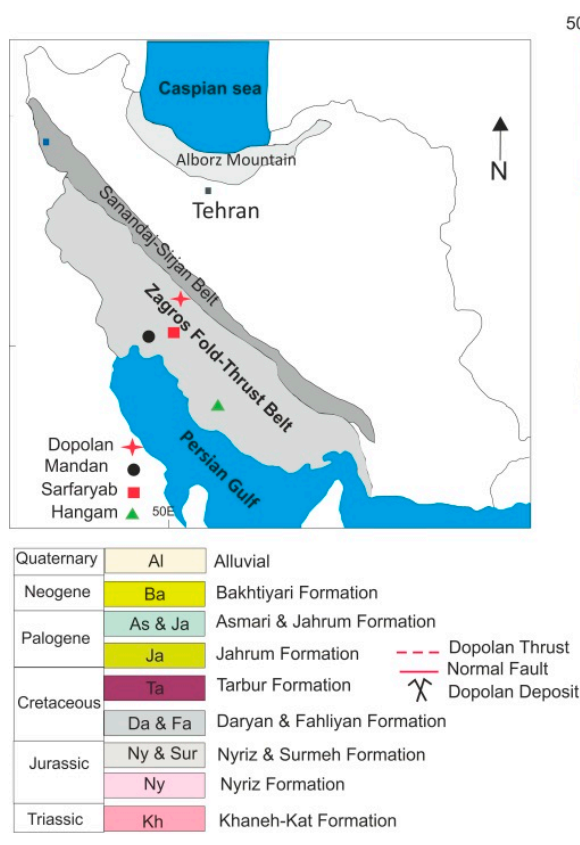

(a)

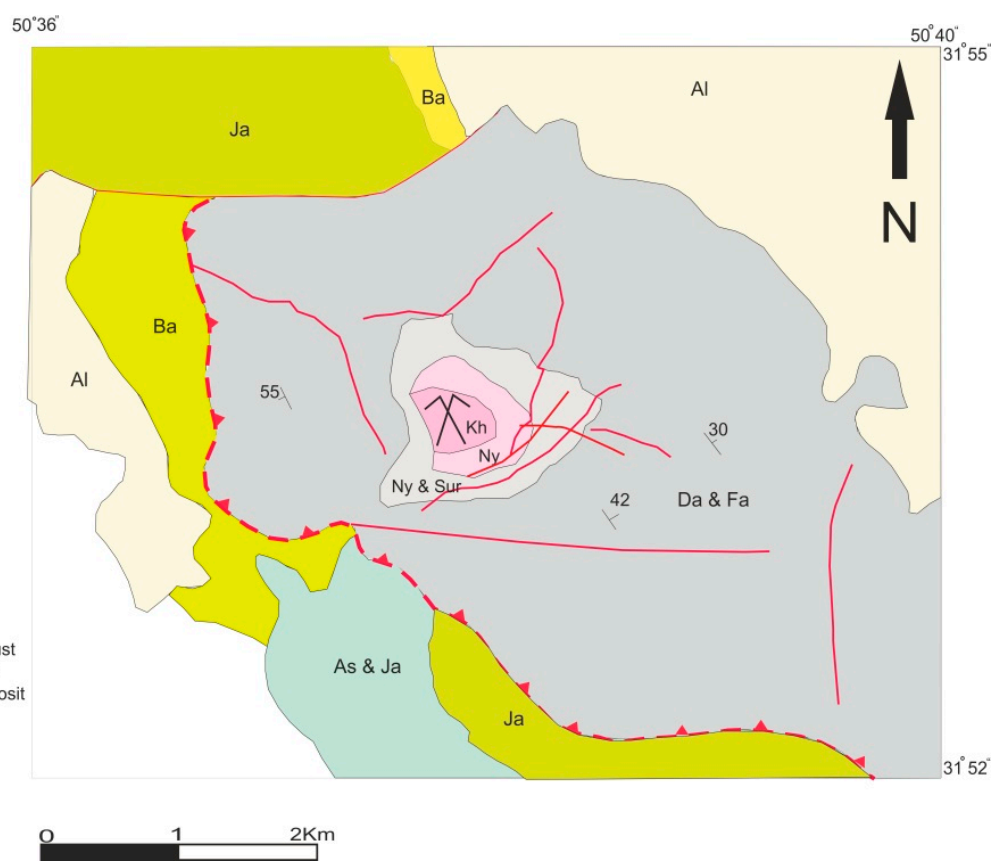

(b)

Figure 1. (a) Location of the Dopolan karstic bauxite in the Zagros fold belt. (b) Geological map of the Dopolan bauxite deposit (modified after [18]).

\section{Methodology}

The exposures of the Dopolan bauxite were divided into four different horizons on the basis of their macromorphological facies and their relation to the foot wall and hanging wall. A total of 28 samples, each weighing $3 \mathrm{~kg}$, of different layers were selected during the fieldwork. Samples were obtained from the topmost part of the Khaneh-Kat Formation, the bauxite profiles, and the lowest part of the Neyriz Formation carbonates in three different cross-sections. Thin and polished sections were prepared for different mineralogical examinations including optical microscopy (both transmitted and reflected), SEM. SEM-Energy dispersive spectrometer (EDS) analysis was performed at the Razi Metallurgical Research Center (Iran), using a Tescan VEGAII XMU-EDS. Minerals were identified using XRD at the Kansaran Binallod, Pardis Science and Technology Park, Tehran, using a Philips X-pert PW diffractometer. The concentrations of major, trace, and rare earth elements (REE) were determined using inductively cople plasma-mass spectroscopy (ICP-MS) by ACME Analytical Lab Ltd., Vancouver, BC, Canada.

Total organic carbon (TOC) of selected samples was determined following the method of Walkey and Black [22]. In this method, organic carbon present in organic matter (OM) is oxidized by chromic acid in the presence of concentrated sulfuric acid.

The analysis of sulfur isotopes was performed on three handpicked pyrite samples and three whole-rock samples from both pyrite-rich and bauxitic kaolinite horizon samples at the University of California, Davis (UC Davis), stable isotope analysis facility (Davis, CA, USA). The $834 S$ was analyzed by an elemental vario isotope cube interfaced to a Ser Con 20-22 IRMS packed with tungsten oxide. The sample gases were reduced with elemental copper at $880{ }^{\circ} \mathrm{C}$. Sample SO2 was passed directly to the isotope ratio mass Spectrometer (IRMS) for measurement. Calibration data were from standards IAEA S.1, S.2, S.3, IAEA-SO-5, IAEA-SO-6, and HHS. The results are given in per mil (\%o ) relative to Vienna Canon diablo Troilite (VCDT). 


\section{Mineralogical Characteristics}

The Dopolan karst bauxite ore [18] mainly consists of diaspore, kaolinite, nacrite, and pyrite (Table 1). Böhmite, anatase, rutile, quartz, and muscovite are present as minor minerals. On the basis of the main mineral contents, the bauxite profile can be divided into four bauxite horizons: bauxitic kaolinite, diaspore-rich bauxite, clay-rich bauxite, and pyrite-rich bauxite (Figure 2).

Table 1. XRD results of the Dopolan deposit [18].

\begin{tabular}{cccc}
\hline Sample No. & Bauxite Layers & Major Phases & Minor Phases \\
\hline Do-org & bauxitic kaolinite & nacrite, kaolinite, pyrite & anatase, rutile \\
Do-oo & diaspore-rich & diaspore, nacrite & anatase, muscovite, rutile \\
Do-pi & diaspore-rich & diaspore & anatase, nacrite, muscovite, rutile \\
Do-cl & clay bauxite & kaolinite, diaspore & anatase, böhmite, muscovite, rutile \\
Do-ir & pyrite-rich & kaolinite, pyrite, nacrite & - \\
Kha & Khaneh-kat dolomite & calcite, dolomite, montmorillonite & \\
\hline
\end{tabular}

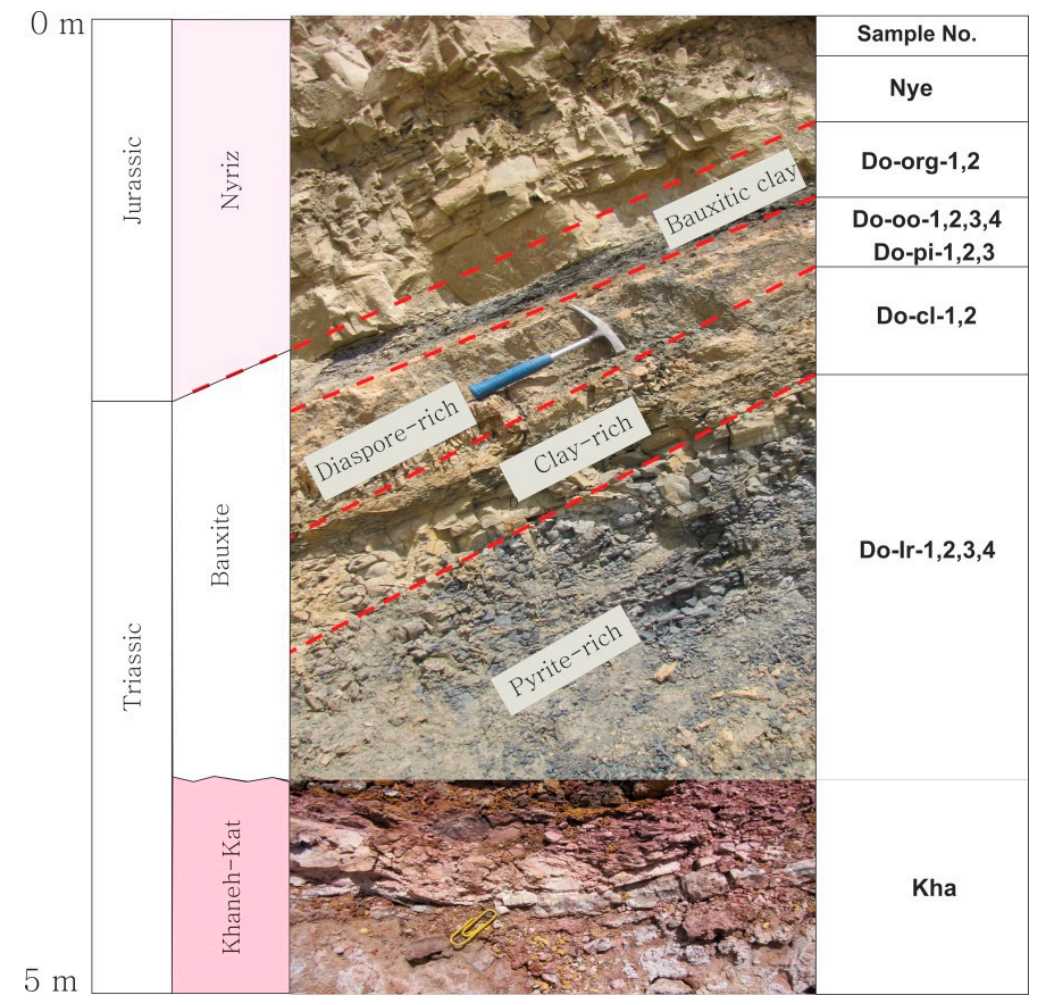

Figure 2. Schematic stratigraphic column of the Dopolan bauxite deposit.

Above the karstified dolomites of the footwall, within the pyrite-rich horizon, the main ore minerals are kaolinite, nacrite, and pyrite; whereas böhmite, muscovite, anatase, and rutile are minor minerals. Optical microscopy, XRD and SEM studies of the pyrite-rich horizon revealed abundant pyrite ( $20 \%$ in modal proportion to more than $35 \%$ ). The pyrite-rich horizon is $\sim 1.5 \mathrm{~m}$ thick. Pyrite grains are mainly framboidal and cubic in shape; some cubic-octahedral crystals are also present (Figure 3). Above the pyrite-rich horizon, in the clay-rich bauxite, the amount of pyrite decreases to less than $5 \%$ in modal proportion. The main minerals in this horizon include kaolinite and diaspore whereas böhmite is minor. The clay-rich bauxite, $\sim 5 \mathrm{~m}$ thick, is gray to light gray in color and has a fine-grained oolitic texture. Up to the top of the bauxite sequence, the amount of kaolinite decreases and diaspore increases to a maximum of $80 \%$ modal. In the diaspore-rich bauxite, minor minerals include nacrite, muscovite, rutile, and anatase. The diaspore-rich bauxite is the main ore zone and is mined. The layer contains an average of $70 \% \mathrm{Al}_{2} \mathrm{O}_{3}, 3 \% \mathrm{Fe}_{2} \mathrm{O}_{3}$, and $2 \% \mathrm{TiO}_{2}$ [18]. This horizon is 
distinguished by its pisolitic and oolitic textures. At the top of the bauxite profile, there is a layer of black bauxitic kaolinite that is enriched in organic matter and is $0.35-1.5 \mathrm{~m}$ thick, indicating a large supply of organic matter in the depositional environment of this layer. In this horizon, kaolinite, nacrite, and pyrite are the main minerals whereas böhmite, diaspore, rutile, and anatase are the minor minerals. The morphology of pyrite in the bauxitic kaolinite horizon is the same as in the pyrite-rich bauxite horizon (Figure 3).
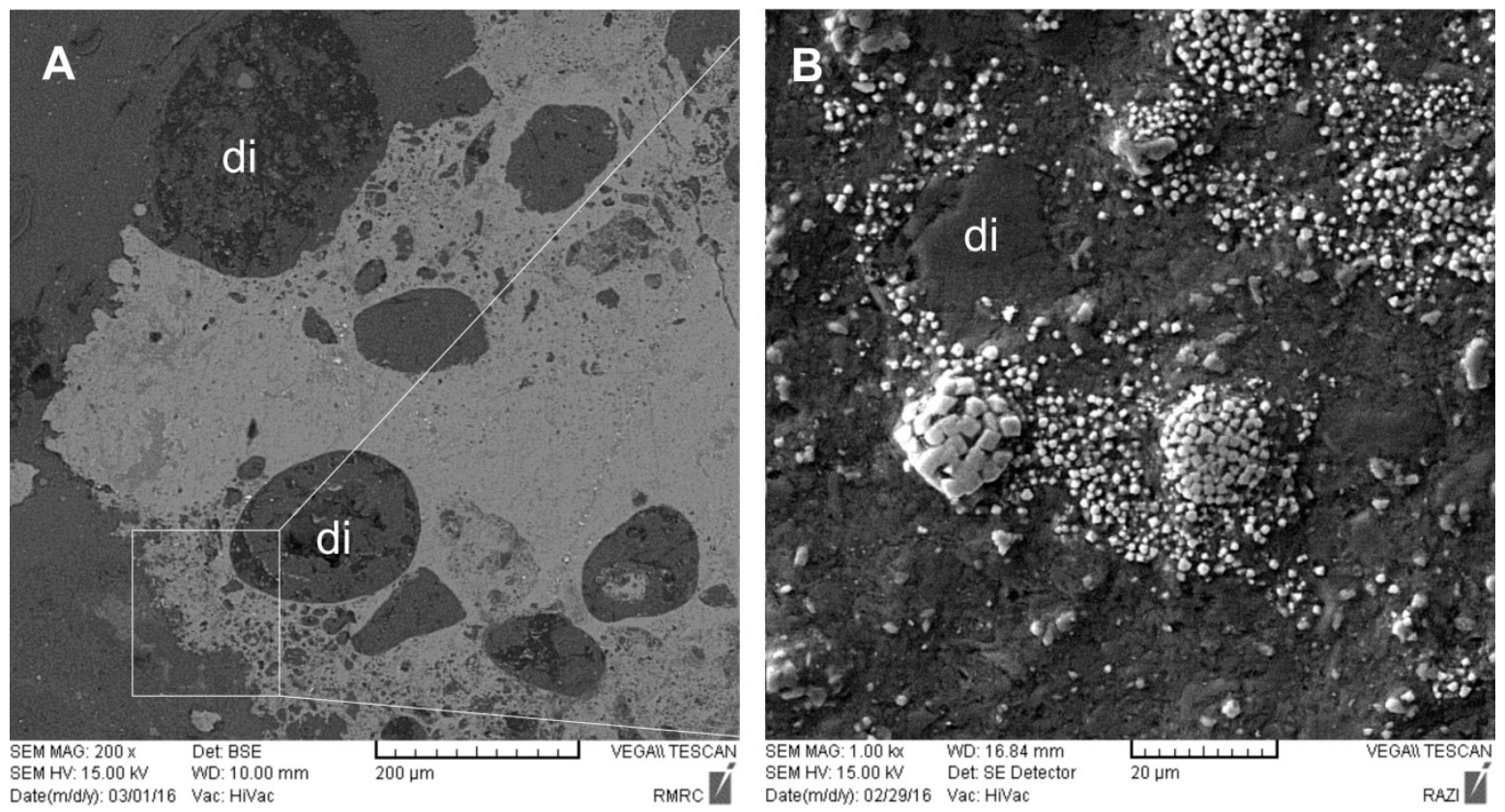

Figure 3. (A) Back scatters images (BSE) showing pyrite with inclusions of diasporic pisoliths (di).

(B) Enlargement of panel A. Different morphological forms of pyrite, spherules of framboidal pyrite, and cubic pyrite. di: diaspore.

\section{Geochemical Features}

\subsection{Distribution of Elements}

The geochemical data (Table 2) confirm the mineralogical results. The aluminum, titanium, potassium, and magnesium contents decrease from the top to bottom of the bauxite profiles, i.e., from the diaspore-rich to the pyrite-rich horizon (Figure 4). In contrast, the silica and iron content increases from the diaspore-rich to the pyrite-rich horizon (Figure 4). REE and immobile elements such as the HFSE (Th, Ta, Nb, Zr, and Hf) are enriched in the diaspore-rich bauxite and decrease to the bottom of the bauxite profile (Figure 4), whereas more mobile elements of the weathering profile such as redox-sensitive elements $(\mathrm{Zn}, \mathrm{Cu}, \mathrm{Ni}, \mathrm{Co}, \mathrm{Ag}, \mathrm{As}, \mathrm{U}$, and $\mathrm{V}$ ) increase from top to bottom (Figure 4). The total content of mobile elements is more than twice that in the pyrite-rich bauxite compared to other horizons. 
Table 2. Chemical composition of the Dopolan bauxite deposit. Measurements for major oxides and sulfur contents are in wt \%; trace elements and rare earth elements (REE) are in ppm.

\begin{tabular}{|c|c|c|c|c|c|c|c|c|c|c|c|c|c|c|c|}
\hline \multirow{2}{*}{$\begin{array}{l}\text { Horizon } \\
\text { Samples }\end{array}$} & \multicolumn{4}{|c|}{ Pyrite-Rich Horizon } & \multicolumn{2}{|c|}{ Clay-Rich Bauxite } & \multicolumn{7}{|c|}{ Diaspore-Rich Bauxite } & \multicolumn{2}{|c|}{ Black Bauxitic Kaolinite } \\
\hline & Do-IR-1 & Do-IR-2 & Do-IR-3 & Do-IR-4 & Do-cl-1 & Do-cl-2 & Do-oo-1 & Do-oo-2 & Do-oo-3 & Do-oo-4 & Do-pi-1 & Do-pi-2 & Do-pi-3 & Do-org-1 & Do-org-2 \\
\hline $\mathrm{SiO}_{2}$ & 7.21 & 16.14 & 14.62 & 11.25 & 35.28 & 31.87 & 7.44 & 5.68 & 5.63 & 3.20 & 4.67 & 5.45 & 3.11 & 34.84 & 35.44 \\
\hline $\mathrm{Al}_{2} \mathrm{O}_{3}$ & 42.02 & 31.34 & 37.58 & 47.1 & 47.39 & 50.69 & 68.11 & 67.78 & 68.23 & 72.89 & 74.98 & 73.25 & 75.09 & 31.1 & 26.55 \\
\hline $\mathrm{Fe}_{2} \mathrm{O}_{3}$ & 19.68 & 21.08 & 16.42 & 11.18 & 25.9 & 1.02 & 3.53 & 2.47 & 4.55 & 0.92 & 2.26 & 2.33 & 1.36 & 5.52 & 7.45 \\
\hline $\mathrm{CaO}$ & 0.06 & 0.10 & 0.04 & 0.13 & 0.06 & 0.05 & 0.07 & 0.11 & 0.04 & 0.03 & 0.04 & 0.08 & 0.07 & 0.90 & 0.13 \\
\hline $\mathrm{K}_{2} \mathrm{O}$ & 0.51 & 1.16 & 0.61 & 0.85 & 0.80 & 0.36 & 0.30 & 0.65 & 0.80 & 1.21 & 0.25 & 1.64 & 0.29 & 4.06 & 3.83 \\
\hline $\mathrm{MnO}$ & 0.01 & 0.02 & 0.01 & 0.00 & 0.00 & 0.00 & 0.00 & 0.00 & 0.00 & 0.00 & 0.00 & 0.00 & 0.02 & 0.03 & 0.00 \\
\hline $\mathrm{Na}_{2} \mathrm{O}$ & 0.01 & 0.01 & 0.01 & 0.06 & 0.01 & 0.01 & 0.01 & 0.02 & 0.01 & 0.07 & 0.01 & 0.04 & 0.06 & 0.05 & 0.12 \\
\hline $\mathbf{P}_{2} \mathrm{O}_{5}$ & 0.10 & 0.09 & 0.08 & 0.07 & 0.06 & 0.07 & 0.10 & 0.07 & 0.09 & 0.08 & 0.13 & 0.12 & 0.15 & 0.06 & 0.05 \\
\hline $\mathrm{MgO}$ & 0.28 & 0.58 & 0.36 & 0.42 & 0.10 & 0.28 & 0.05 & 0.41 & 0.10 & 0.24 & 0.02 & 0.03 & 0.34 & 0.32 & 0.91 \\
\hline $\mathrm{TiO}_{2}$ & 1.47 & 1.07 & 1.75 & 1.50 & 1.92 & 2.38 & 2.15 & 2.35 & 2.35 & 2.65 & 2.83 & 2.34 & 2.77 & 0.95 & 0.94 \\
\hline LOI & 26.3 & 25.9 & 28.13 & 26.32 & 11.27 & 12.62 & 17.35 & 20.36 & 16.89 & 17.82 & 15.42 & 15.67 & 16.56 & 22.67 & 23.24 \\
\hline TOC & 0.42 & 0.37 & - & - & 0.18 & 0.2 & - & 0.18 & - & - & 0.016 & 0.21 & - & 1.00 & 1.14 \\
\hline Sum & 97.64 & 97.48 & 99.62 & 98.88 & 99.47 & 99.35 & 99.12 & 99.89 & 98.69 & 99.11 & 100.62 & 100.96 & 99.82 & 100.50 & 98.66 \\
\hline $\mathbf{B i}$ & 0.89 & 0.75 & 0.9 & 0.75 & 0.82 & 0.7 & 1.4 & 0.55 & 1.82 & 0.69 & 1.01 & 0.53 & 0.43 & 0.89 & 0.53 \\
\hline As & 29 & 48 & 51 & 49 & 7.5 & 6 & 1 & 4.6 & 27.3 & 30 & 5.2 & 5.9 & 4.8 & 1 & 1 \\
\hline $\mathrm{Cd}$ & 1.4 & 2.21 & 2.37 & 2.25 & 0.59 & 0.33 & 0.89 & 0.64 & 1.24 & 1.75 & 0.27 & 0.05 & 0.66 & 0.3 & 0.13 \\
\hline $\mathbf{N i}$ & 340 & 394 & 345 & 382 & 296 & 290 & 236 & 150 & 111 & 273 & 220 & 258 & 170 & 407 & 270 \\
\hline Co & 203 & 179 & 155 & 197 & 5.2 & 8.3 & 6.4 & 5.7 & 43.1 & 172 & 143 & 4.6 & 2.7 & 17.9 & 11 \\
\hline $\mathrm{Cr}$ & 429 & 286 & 577 & 381 & 359 & 255 & 486 & 442 & 389 & 329 & 132 & 139 & 303 & 747 & 1088 \\
\hline Cs & 0.18 & 0.26 & 0.15 & 0.36 & 0.11 & 0.28 & 0.05 & 0.13 & 0.22 & 8.3 & 0.15 & 0.33 & 0.03 & 3.39 & 3.21 \\
\hline $\mathrm{Cu}$ & 403 & 184 & 389 & 144 & 92 & 63 & 155 & 102 & 228 & 143 & 151 & 70.7 & 9 & 65.2 & 50.2 \\
\hline $\mathrm{Pb}$ & 212 & 189 & 180 & 130 & 43 & 28 & 30 & 101 & 77 & 25.5 & 56 & 44 & 5 & 44 & 35 \\
\hline Hf & 6.63 & 6.54 & 13.6 & 9.66 & 8.89 & 14.82 & 12.2 & 9.93 & 18.9 & 17.72 & 16.87 & 15.46 & 17.78 & 5.29 & 6.21 \\
\hline $\mathrm{Ag}$ & 4.02 & 3.41 & 8.59 & 5.50 & 2.1 & 2.7 & 3.1 & 2.37 & 2.95 & 3.11 & 1.48 & 0.96 & 0.33 & 1.63 & 0.94 \\
\hline $\mathrm{La}$ & 8.7 & 17 & 9.9 & 18.5 & 1 & 3.5 & 9.9 & 1.8 & 23.8 & 24 & 8.9 & 0.3 & 1.2 & 44.2 & 62.12 \\
\hline $\mathrm{Ce}$ & 28.9 & 47.9 & 38.6 & 54 & 2.01 & 0.88 & 10.1 & 4.47 & 56 & 198 & 12.8 & 0.6 & 30.04 & 87.9 & 98 \\
\hline Pr & 3.23 & 5.64 & 4.35 & 4.2 & 0.32 & 0.2 & 1.94 & 0.71 & 4.62 & 23.97 & 2.09 & 0.08 & 0.4 & 10.3 & 16.69 \\
\hline $\mathrm{Nd}$ & 14.1 & 25 & 19.9 & 14.71 & 1.09 & 12.7 & 5.48 & 2.76 & 14 & 94.0 & 6.69 & 0.28 & 0.25 & 38.3 & 10.56 \\
\hline $\mathrm{Sm}$ & 2.86 & 7.29 & 3.96 & 9.04 & 0.36 & 0.1 & 1.06 & 0.76 & 2.84 & 7.76 & 1.13 & 0.09 & 0.03 & 6.73 & 2.48 \\
\hline $\mathrm{Eu}$ & 0.57 & 2.18 & 0.95 & 1.53 & 0.11 & 1.98 & 0.28 & 0.2 & 0.52 & 1.4 & 0.21 & 0.05 & 1.44 & 1.35 & 3.51 \\
\hline $\mathrm{Gd}$ & 4.25 & 18.3 & 5.83 & 7.32 & 0.7 & 0.38 & 1.62 & 0.99 & 3.58 & 5.66 & 1.43 & 0.16 & 6.7 & 8.87 & 16.25 \\
\hline Dy & 4.59 & 28.4 & 5.79 & 13.95 & 0.86 & 10.95 & 1.47 & 1.43 & 3.4 & 8.36 & 1.68 & 0.23 & 1.85 & 6.02 & 8.04 \\
\hline Ho & 0.98 & 5.73 & 1.16 & 3.21 & 0.2 & 2.24 & 0.29 & 0.28 & 0.73 & 1.81 & 0.32 & 0.05 & 0.2 & 1.13 & 2.64 \\
\hline Er & 2.86 & 14.9 & 3.75 & 9.9 & 0.63 & 0.74 & 0.79 & 0.87 & 2.27 & 5.48 & 0.99 & 0.2 & 0.8 & 3.38 & 7.34 \\
\hline
\end{tabular}


Table 2. Cont.

\begin{tabular}{|c|c|c|c|c|c|c|c|c|c|c|c|c|c|c|c|}
\hline \multirow{2}{*}{$\begin{array}{l}\text { Horizon } \\
\text { Samples }\end{array}$} & \multicolumn{4}{|c|}{ Pyrite-Rich Horizon } & \multicolumn{2}{|c|}{ Clay-Rich Bauxite } & \multicolumn{7}{|c|}{ Diaspore-Rich Bauxite } & \multicolumn{2}{|c|}{ Black Bauxitic Kaolinite } \\
\hline & Do-IR-1 & Do-IR-2 & Do-IR-3 & Do-IR-4 & Do-cl-1 & Do-cl-2 & Do-oo-1 & Do-oo-2 & Do-oo-3 & Do-oo-4 & Do-pi-1 & Do-pi-2 & Do-pi-3 & Do-org-1 & Do-org-2 \\
\hline $\mathrm{Tm}$ & 0.47 & 2.02 & 0.63 & 1.64 & 0.12 & 1.1 & 0.15 & 0.15 & 0.43 & 0.92 & 0.15 & 0.05 & 0.1 & 0.48 & 1.2 \\
\hline $\mathrm{Yb}$ & 2.8 & 10.4 & 4 & 11.1 & 0.7 & 7.4 & 1 & 1 & 2.6 & 6.34 & 0.8 & 0.3 & 0.5 & 3 & 7.41 \\
\hline Lu & 0.41 & 1.5 & 0.62 & 1.71 & 0.12 & 1.15 & 0.14 & 0.14 & 0.41 & 0.89 & 0.12 & 0.03 & 0.78 & 0.47 & 0.9 \\
\hline Th & 24.5 & 25.7 & 34.3 & 36.16 & 21.54 & 49.64 & 44.52 & 28.41 & 46.35 & 51.92 & 38.57 & 38.75 & 54.66 & 10.6 & 17.34 \\
\hline $\mathrm{Zn}$ & 96 & 101 & 197 & 122 & 144 & 123 & 145 & 97.2 & 117 & 120 & 69.5 & 51.5 & 5 & 48.2 & 21 \\
\hline $\mathrm{Zr}$ & 246 & 250 & 340 & 364 & 271 & 583 & 419 & 308 & 557 & 535.8 & 467.2 & 437.8 & 478.4 & 206 & 132 \\
\hline Mo & 4.09 & 8.44 & 3.93 & 6.74 & 25.9 & 20.5 & 15.4 & 21 & 32.3 & 28 & 3.83 & 13.9 & 7 & 1.35 & 1.4 \\
\hline $\mathrm{Nb}$ & 43.1 & 35.3 & 46.2 & 38.34 & 45.6 & 54.43 & 52.6 & 54.7 & 77.7 & 67.9 & 41.4 & 28.4 & 62.4 & 38.2 & 33.8 \\
\hline$S$ & $>5$ & $>5$ & $>5$ & $>5$ & 1 & 2.1 & 1.4 & 1.5 & 2.5 & 1.75 & 1.2 & 1.4 & 1.2 & 2.2 & 1.7 \\
\hline $\mathrm{Sb}$ & 10.6 & 4.44 & 11.7 & 9.65 & 3.89 & 2.52 & 2.74 & 2.34 & 6.53 & 4.33 & 2.84 & 2.51 & 1.99 & 0.36 & 0.23 \\
\hline $\mathrm{Ta}$ & 4.58 & 3.87 & 6.21 & 2.72 & 4.4 & 4.97 & 5.35 & 5.19 & 7.2 & 8.1 & 5.6 & 3.1 & 6.4 & 3.6 & 2.9 \\
\hline $\mathrm{Tl}$ & 0.19 & 1.12 & 0.2 & 0.56 & 0.18 & 0.1 & 0.12 & 0.14 & 0.37 & 0.25 & 0.09 & 0.21 & 0.38 & 0.18 & 0.22 \\
\hline $\mathbf{U}$ & 67.4 & 70.4 & 111 & 35.05 & 6.8 & 27.12 & 9.2 & 10.2 & 23.4 & 17.4 & 11.1 & 2.3 & 11.6 & 2.6 & 9.4 \\
\hline V & 1250 & 759 & 1441 & 472 & 272 & 310 & 186 & 330 & 365 & 485 & 277 & 304 & 442 & 107 & 163 \\
\hline $\mathbf{Y}$ & 17.1 & 147 & 17.8 & 55 & 3.2 & 4.6 & 6 & 4.6 & 13.9 & 41.06 & 5.5 & 1.2 & 56.34 & 29.9 & 55.4 \\
\hline
\end{tabular}



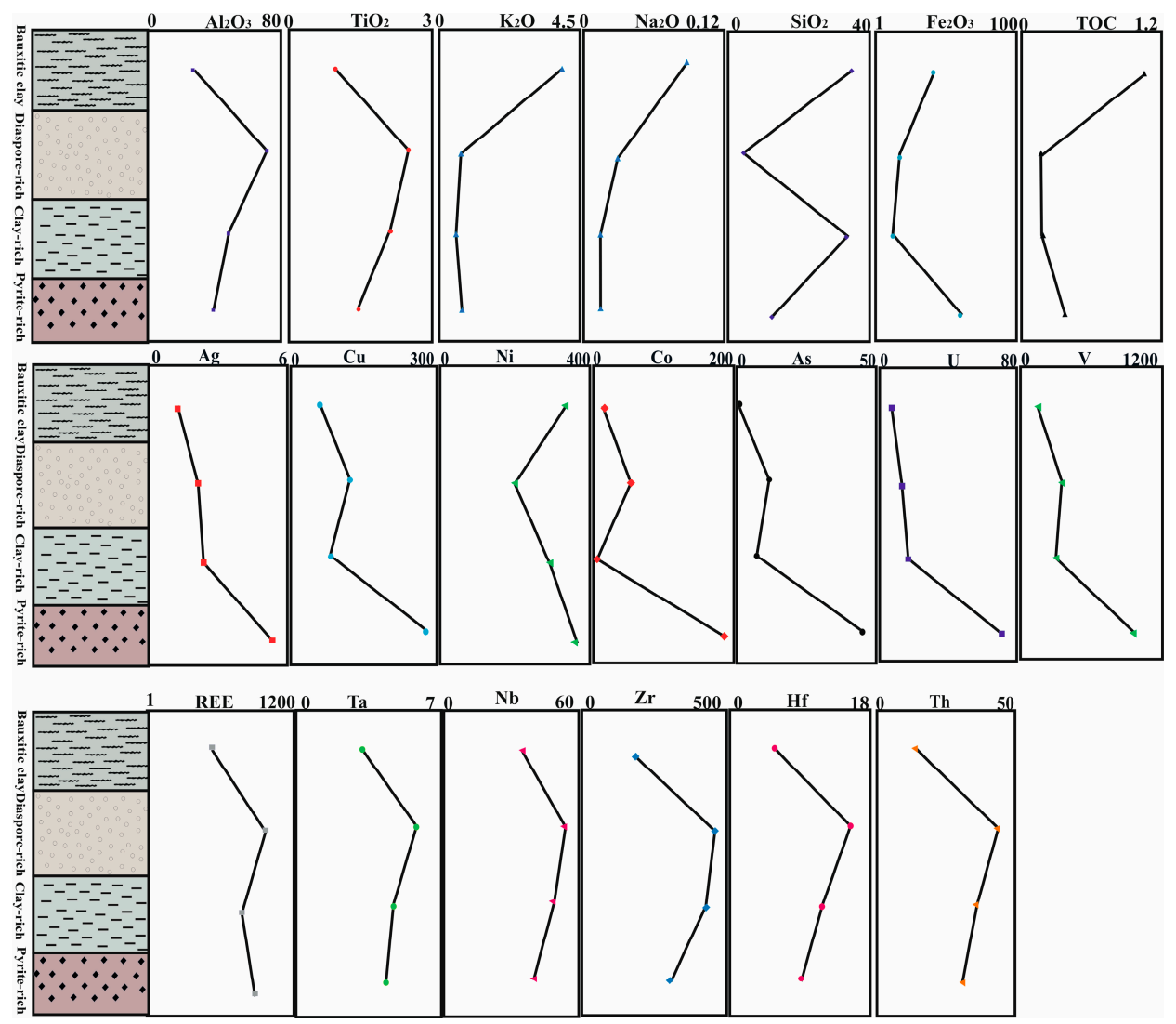

Figure 4. Variations in major oxides (in wt \%), $\sum R E E$, and selected trace elements (in ppm) in the Dopolan bauxite sequence in response to Total organic content (TOC). Points refer to the average content of the selected samples.

\subsection{Organic Matter of Bauxite Horizons}

The TOC content of different bauxite horizons, foot, and hanging walls of the Dopolan bauxite was calculated (Table 2) to investigate the relationship between elemental mobility and TOC. The TOC content of the Dopolan bauxite deposits varies from $0.18 \%$ in the diaspore-rich bauxite to $1 \%$ in the bauxitic kaolinite. Both the lowest and the uppermost parts of the bauxitic profile, which have higher TOC contents, have higher contents of pyrite. The alumina content of bauxite samples displays a negative correlation with TOC (Figure 5). The REE behavior in bauxite horizons is the inverse of those of Fe and TOC (Figure 4).

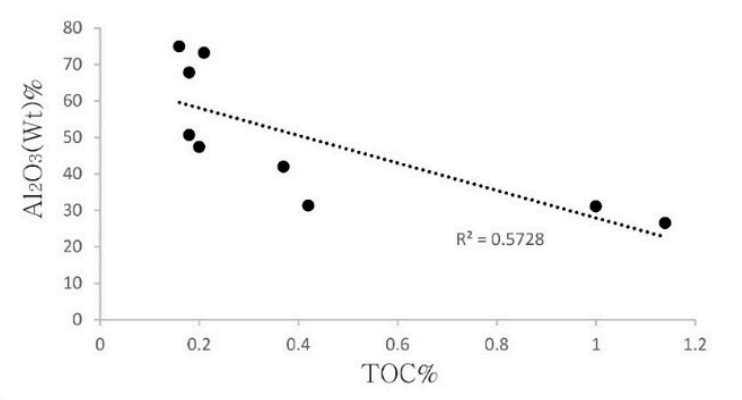

Figure 5. $\mathrm{Al}_{2} \mathrm{O}_{3}$ and TOC values of the Dopolan samples, displaying a negative correlation coefficient. 


\subsection{Sulfur Isotopes}

The $\delta^{34} S$ values of handpicked pyrites from the pyrite-rich bauxite horizon and whole-rock from the bauxitic kaolinite and pyrite-rich bauxite samples display a wide negative range, from $-10.12 \%$ o to $-34.58 \%$ (Table 3; Figure 6). However, the $\delta^{34} \mathrm{~S}$ values of the bauxitic kaolinite vary from $-26.77 \% 0$ to $-33.58 \%$, exhibiting a narrower range than that of the pyrite-rich bauxite samples $(-10.12 \%$ to $-34.59 \%$ ).

Table 3. Sulfur isotope compositions of pyrite and whole-rock samples from the Dopolan deposit.

\begin{tabular}{cccc}
\hline Sample No. & Horizon & Description & $\boldsymbol{\delta}^{\mathbf{3 4}} \mathbf{S}$ \\
\hline S-1 & pyrite-rich & whole rock & -34.59 \\
S-2 & pyrite-rich & separated pyrite & -34.47 \\
S-3 & pyrite-rich & separated pyrite & -10.12 \\
S-4 & bauxitic kaolinite & separated pyrite & -26.77 \\
S-5 & bauxitic kaolinite & whole rock & -33.58 \\
S-6 & bauxitic kaolinite & whole rock & -28.63 \\
\hline
\end{tabular}

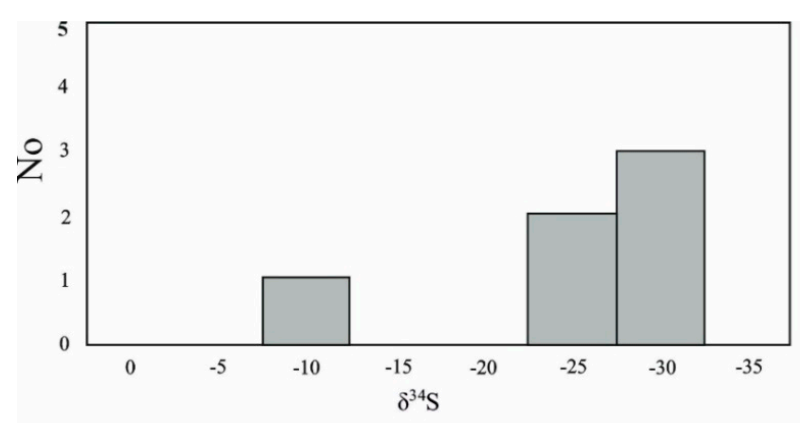

Figure 6. Frequency histogram of the $\delta^{34} S$ values of the Dopolan bauxite deposit.

\section{Discussion}

\subsection{Formation of the Pyrite-Rich Horizon}

Significant amounts of pyrite were deposited in the lowest part of the bauxite sequence of the Dopolan deposit, forming an unusual pyrite-rich horizon. The presence of Fe-oxy-hydroxide minerals in bauxitic horizons is commonly reported, but pyrite-rich bauxites are uncommon and have been described from only some areas, such as the Taurides region in Turkey [1]; the Minjera deposit, Croatia; and the gray part of the Parnassos-Ghiona bauxite deposit in Greece [3]. The TOC values of the Dopolan bauxite ore vary from $0.18 \%$ in the diaspore-rich bauxite, $0.2 \%$ in the clay-rich bauxite, $0.4 \%$ in the pyrite rich bauxite, and up to $1 \%$ in the upper bauxitic kaolinite horizon. These data indicate that the TOC content of the Dopolan bauxite is higher than that of most bauxite deposits of the world $[3,4]$. The high content of preserved organic matter in the gray bauxite of the Dopolan resulted in reducing conditions caused by decomposition of the organic matter. In these conditions, the sparingly soluble $\mathrm{Fe}^{3+}$ was reduced to more soluble $\mathrm{Fe}^{2+}$ [23], which is leached out from the upper part of the sequence. Microorganisms could accelerate this reaction by their enzymes or metabolism. In water-saturated soils, microbial reduction of Fe oxides in the presence of organic matter facilitates mobility and removal of iron from the soil profile [24,25]:

$$
4 \mathrm{FeOOH}+\mathrm{CH}_{2} \mathrm{O}+8 \mathrm{H}^{+}=4 \mathrm{Fe}^{2+}+\mathrm{CO}_{2}+7 \mathrm{H}_{2} \mathrm{O} .
$$


Hydrogen sulfide is produced from the reduction of sulfate by a variety of bacterial species, e.g., Desulfovibrio desulfuricans, when organic matter as an energy source is present as a reducing agent $[3,26]$. The following reaction has been proposed [27-30]:

$$
2 \mathrm{CH}_{2} \mathrm{O}+\mathrm{SO}_{4}{ }^{2+} \rightarrow \mathrm{H}_{2} \mathrm{~S}+2 \mathrm{HCO}^{3-}
$$

Bacteria fossils and associated microorganisms with the pyrite are the best evidence for the aforementioned conditions (Figure 7). The morphology of pyrite is essentially related to the degree of $\mathrm{Fe}$ and $\mathrm{S}$ saturation of pore water [31-33]. If the interstitial water is supersaturated with respect to FeS, monosulfides are deposited. When these monosulfides change to pyrite, the pyrite will have a spherulitic morphology and form clusters of well-formed grains and euhedral crystals (Figure 3). If pyrite is directly deposited from solution, the most common morphology is cubic to cubic-octahedral [34]. Therefore, the cubic-octahedral morphology of the Dopolan pyrite is due to the saturation of pore water with respect to iron and sulfur.
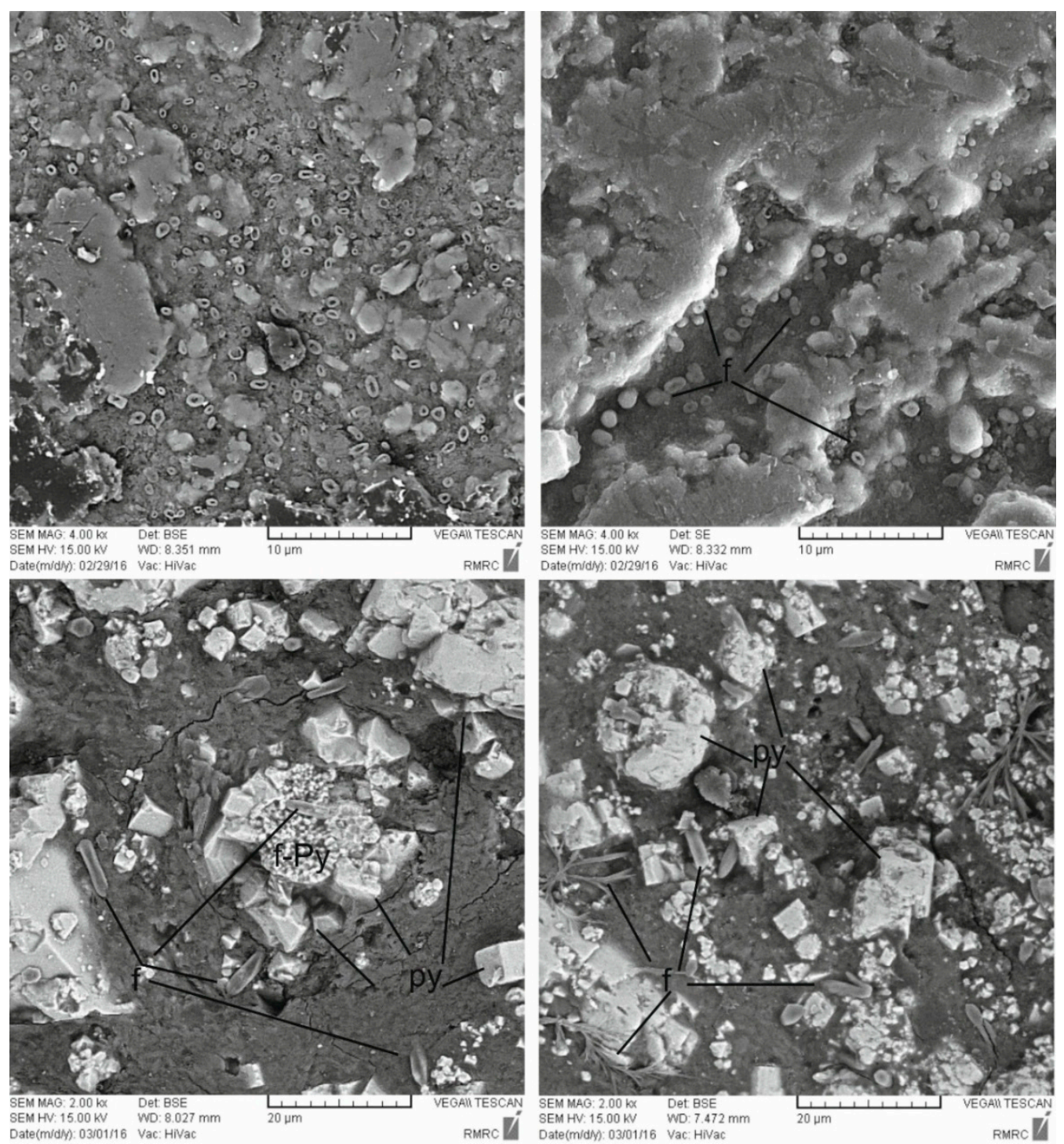

Figure 7. Representative back-scattered images showing different types of bacterial fossils and filamentous microorganisms (f) between pyrite (py: cubic pyrite; f-py: framboidal pyrite) in the Dopolan bauxite deposit. 


\subsection{Deposition Mechanisms of High-Grade Al Bauxite}

It is well known that the solubilization of $\mathrm{Al}$ and $\mathrm{Si}$ in bauxite profiles is particularly sensitive to $\mathrm{pH}$, but the rate of Fe mobility is mainly controlled by both $\mathrm{pH}$ and Eh [35-37]. In bauxite profiles, many factors can influence $\mathrm{pH}$, such as organic matter content, $\mathrm{CO}_{2}$ availability, standing electrolyte content, and the nature of the host rock [38,39]. The $\mathrm{pH}$ range in karstic bauxite is 5-9; however, most deposits have a $\mathrm{pH}$ range of 6-8. In the $\mathrm{pH}$ range of 5-9, the solubility of $\mathrm{Si}$ is 10-20 times greater than that of $\mathrm{Al}$ and $\mathrm{Fe}$. Thus, after long-term weathering, significant dissolution of $\mathrm{Si}$ will have taken place, but $\mathrm{Fe}$ and $\mathrm{Al}$ will remain. For a constant environmental $\mathrm{pH}$, the solubility of Fe can increase in competition to $\mathrm{Al}$ as a result of decreasing Eh [35,40,41]. Laskou and Economou-Eliopoulos [3] argued for a close relationship between iron leaching and alumina enrichment in the gray and red ores of the Parnassos-Ghiona deposits, Greece. The Dopolan bauxite deposit, with an average of 3\% $\mathrm{Fe}$, is essentially iron-poor bauxite (except for the pyrite-rich horizon, which has an average of $13 \%$ $\mathrm{Fe}$ ). Fe leaching could take place during (syngenetic) or after (epigenetic) bauxite deposition [3,35]. Diaspore formed in a mildly reduced and alkaline environment and pyrite should precipitate under mildly acidic conditions. Therefore, the environmental conditions of the Dopolan bauxite deposit, based on the predominant ore minerals such as diaspore, pyrite, and kaolinite were changed from acidic reducing to slightly alkaline reducing (Figure 8). The existence of reducing conditions can also be deduced by the presence of the high content of organic matter. Field evidence such as the presence of plant root casts show that the Dopolan bauxite deposit formed in a swamp sedimentary basin. The high organic matter content of the Dopolan bauxite probably results from plant root casts as bauxite deposition was a preferred system for plant growth $[18,42]$.

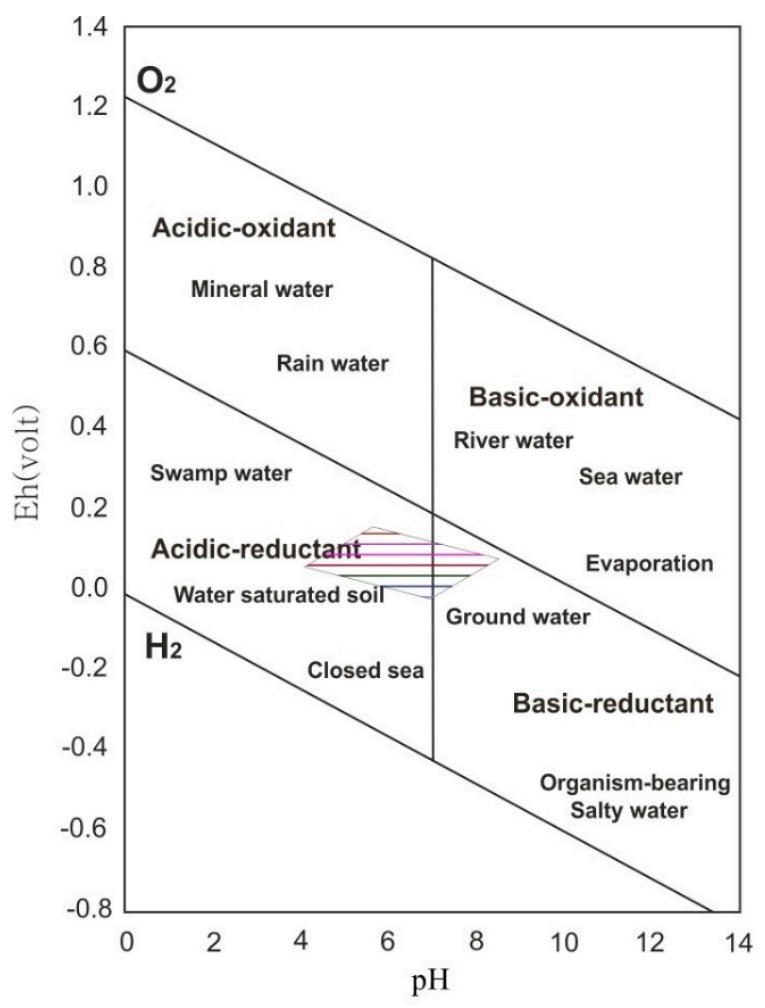

Figure 8. Eh-pH diagram illustrating the natural environmental conditions $[40,43]$ of the stability fields of minerals in the Dopolan deposits. The thermodynamic data of the diagram were $T=25^{\circ}$ and $p=1$ bar. 
Therefore, the main difference between the depositional environments of the Dopolan bauxite deposit and other Zagros bauxite deposits may be the greater reducing conditions, which caused Fe- leaching and $\mathrm{Al}$ enrichment (Table 4).

Table 4. Mineral descriptions and comparative $\mathrm{Fe}_{2} \mathrm{O}_{3}, \mathrm{SiO}_{2}$, and $\mathrm{Al}_{2} \mathrm{O}_{3}$ contents of the Zagros bauxite deposits.

\begin{tabular}{|c|c|c|c|c|c|}
\hline Deposit & Main Minerals & $\mathrm{Al}_{2} \mathrm{O}_{3}(\mathrm{wt} \%)$ & $\mathrm{SiO}_{2}(\mathrm{wt} \%)$ & $\mathrm{Fe}_{2} \mathrm{O}_{3}(\mathrm{wt} \%)$ & Reference \\
\hline Dopolan & diaspore-kaolinite-pyrite-nacrite & $38-71$ & $5-35$ & $2-17$ & {$[18]$} \\
\hline Sarfaryab & böhmite $>$ gibbsite-calcite-kaolinite-hematite & $18-63$ & $6-14$ & $2-18$ & [15] \\
\hline Dehnow & böhmite-calcite-kaolinite-hematite & $34-64$ & $4-8$ & $3-21$ & [16] \\
\hline Mandan & böhmite-calcite-kaolinite-hematite & $12-56$ & $3-30$ & $1-24$ & {$[16]$} \\
\hline Hangam & böhmite-kaolinite-hematite-goethite & $17-45$ & $15-19$ & $16-20$ & [14] \\
\hline
\end{tabular}

\subsection{Mobility of REE and Trace Elements}

The mobility of REE and trace elements in bauxite deposits is dependent on the physico-chemical conditions of pore water as it percolates through the soil [3,44-46]. Under oxidizing conditions, the solubility and deposition of REE are similar to those of $\mathrm{Al}_{2} \mathrm{O}_{3}, \mathrm{P}_{2} \mathrm{O}_{5}$, and $\mathrm{TiO}_{2}$. In addition, the concentration of other immobile elements such as $\mathrm{Zr}, \mathrm{Nb}$, Ta, and $\mathrm{Hf}$ increase with increasing $\mathrm{Al}_{2} \mathrm{O}_{3}$, $\mathrm{P}_{2} \mathrm{O}_{5}$, and $\mathrm{TiO}_{2}$ [47-49]. The REE can be absorbed by or adsorbed onto diaspore and böhmite. However, the high positive correlation between REE and $\mathrm{P}_{2} \mathrm{O}_{5}$ in the Dopolan karstic bauxite suggests that at the least some REE can be accommodated in the structure of some phosphates (i.e., Al-phosphates or members of the rhabdophane group). The mildly positive correlation of HFSE with $\mathrm{TiO}_{2}$ suggests that these elements can be accommodated in the structure of $\mathrm{TiO}_{2}$ polymorphs, as rutile. The highest contents of $\mathrm{Al}_{2} \mathrm{O}_{3}, \mathrm{TiO}_{2}, \mathrm{P}_{2} \mathrm{O}_{5}, \mathrm{Zr}, \mathrm{Nb}, \mathrm{Ta}$, and $\mathrm{Hf}$ were detected in the diaspore-rich bauxite, implying similarity of the geochemical characteristics during deposition (Figure 9) [50,51]. In contrast, the lowest contents of these elements were detected in the bauxitic kaolinite horizon with the lowest weathering rate and highest organic matter content. Therefore, the concentrations of these elements are mainly controlled by weathering factors $[18,46,48,50-52]$. The presence of organic matter in the bauxite profile caused reducing conditions, favoring the removal of REE and other immobile elements [3].

In contrast to REE and other immobile elements, which are enriched in the diaspore-rich horizon, the more mobile trace elements (e.g., $\mathrm{Cu}, \mathrm{Ni}, \mathrm{Co}, \mathrm{Cr}, \mathrm{Pb}, \mathrm{Zn}, \mathrm{Sb}, \mathrm{Ag}, \mathrm{As}, \mathrm{U}$, and $\mathrm{V}$ ) are enriched in the pyrite-rich bauxite horizon with higher organic matter $(0.37 \%)$ and lower $\mathrm{Al}_{2} \mathrm{O}_{3}$. These elements are more than twice as abundant in the pyrite-rich bauxite horizon $(2200 \mathrm{ppm})$ than in the diaspore-rich ( $870 \mathrm{ppm})$ and clay bauxite $(850 \mathrm{ppm})$ horizons. These elements appear to have been leached from the upper parts of the bauxitic profile and become precipitated in the lower part of the weathering profile in which the upper parts are more acidic and oxidizing but the lower pyrite-rich horizon is slightly acidic to alkaline and more reducing.

For the $\mathrm{pH}$ range 4-8 [53], it has been demonstrated that the mobility of most elements increased in soils with increasing Eh and vice versa. Additionally, some bacteria can play an important role in the mobility and precipitation of multiple redox state elements (e.g., $\mathrm{Cu}, \mathrm{Fe}, \mathrm{Mn}, \mathrm{Cr}$, and $\mathrm{V}$ ) by means of their metabolic products [11,54-56]. Microorganism activity in the Dopolan bauxite deposit was demonstrated by microbial pyrite deposition (Section 6.2), and sulfur isotopic evidence (Section 6.4). Other important factors for the fixation of more mobile elements in the Dopolan deposit can be absorption by and/or adsorption onto the surface of pyrite and co-precipitation by clay minerals. Negatively charged surfaces of clay minerals offer extensive surfaces to adsorb positive charge elements largely in the $\mathrm{pH}$ range of 5 to $8[7,10,11,54-56]$. 


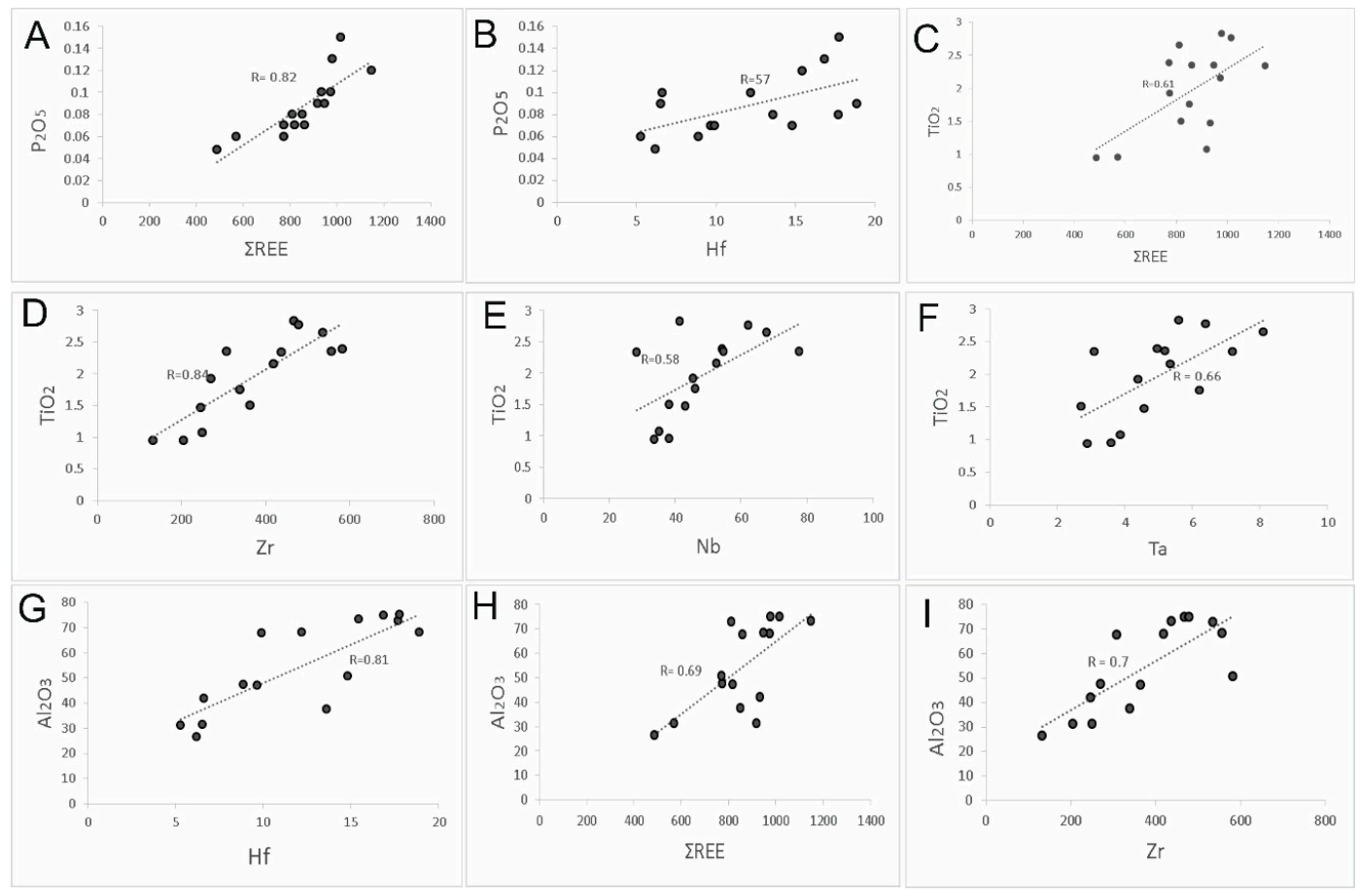

Figure 9. Variation diagrams showing the correlations between selected trace elements and $\mathrm{Al}_{2} \mathrm{O}_{3}$, $\mathrm{P}_{2} \mathrm{O}_{5}$, and $\mathrm{TiO}_{2}$. Positive correlation between $\mathrm{P}_{2} \mathrm{O}_{5}$ and $\sum \mathrm{REE}(\mathbf{A})$; mildly positive correlation between $\mathrm{P}_{2} \mathrm{O}_{5}$ and $\mathrm{Hf}(\mathbf{B})$; mildly positive correlation between $\mathrm{TiO}_{2}$ and $\sum \mathrm{REE}(\mathbf{C}) ; \mathrm{Zr}(\mathbf{D}) ; \mathrm{Nb}(\mathbf{E}) ; \mathrm{Ta}(\mathbf{F})$; Positive correlation between $\mathrm{Al}_{2} \mathrm{O}_{3}$ and $\mathrm{Hf}(\mathbf{G})$; mildly positive correlation between $\mathrm{Al}_{2} \mathrm{O}_{3} \sum \mathrm{REE}(\mathbf{H}) ; \mathrm{Zr}(\mathbf{I})$.

\subsection{Sulfur Isotope Constraints}

The $\delta^{34} \mathrm{~S}$ values have been used as a tracer for biogenic sulfate reduction and reconstruction of paleoenvironments [57]. Pyrite formation in sedimentary and low-temperature environments has been well studied because of the relation between redox conditions and the biogeochemical cycles of sulfur, iron, and carbon [58]. The whole-rock and pyrite $\delta^{34} \mathrm{~S}$ values of the Dopolan bauxite deposit fall in a wide negative range, from $-10 \%$ to $-34 \%$, suggesting involvement of bacterial sulfate reduction after bauxitization. Sulfur isotope variation is dependent on the occurrence of sulfate reduction in an open or closed system [59]. Negative $\delta^{34} S$ values of pyrite imply fractionation by microorganisms during their sulfur metabolism by sulfate reduction in an open system $[29,30,33]$. The bacteria and microorganisms grew in a temperature range of $28-60{ }^{\circ} \mathrm{C}$ [60]. The negative sulfur values previously reported for Turkish bauxite deposits (Dogøankuzu and Mortas deposits; [1]) and the Parnassos-Ghiona deposit in Greece [4] are comparable to those of the Dopolan deposit and have been attributed to the reduction of sulfate by bacteria [4]. Surface water is the probable source of the sulfur, as indicated in other places $[60,61]$.

\section{Conclusions}

The high-grade, gray-colored Dopolan bauxite deposit is found in the Triassic carbonates of the Khaneh Kat Formation. This deposit is a diaspore-rich karst-type bauxite with low Fe content and an unusual pyrite-rich horizon in the lowest part of the sequence. This study has focused on the role of organic matter and microorganisms in the bioleaching of elements, e.g., upgrading the alumina content of the deposit. The study offers the following conclusions:

1. The main minerals, such as diaspore, pyrite, kaolinite, and its association with preserved organic matter, suggest that bauxitization occurred in acidic reducing to slightly alkaline reducing conditions. 
2. The low Fe content of the Dopolan bauxite implies that Fe leaching under reducing conditions may have resulted from organic matter in the presence of microbial activity. Fe was leached from the upper part of the bauxite profile and was deposited as pyrite in the lower part, generating a pyrite-rich bauxite horizon.

3. During the formation of the bauxite profile, less mobile elements, such as $\mathrm{REE}, \mathrm{Nb}, \mathrm{Ta}, \mathrm{Zr}$, and $\mathrm{Hf}$, accumulated in the diaspore-rich horizon with higher alumina content, whereas redox sensitive elements such as $\mathrm{Cr}, \mathrm{Ni}, \mathrm{Ag}, \mathrm{Cu}, \mathrm{Pb}, \mathrm{Zn}, \mathrm{U}$, and $\mathrm{V}$, were concentrated in the pyrite-rich horizon.

4. Sulfur isotope data reveal a wide range of negative values of $\delta^{34} \mathrm{~S}$ for pyrite samples (from $-10 \%$ to $-34 \%$ ) , suggesting the biogeochemical reduction of sulfate to sulfur.

5. Mineralogical data, geochemical evidence, and sulfur isotope data in this study suggest that biological activity played an important role in Fe remobilization, Al-upgrading, and the formation of the pyrite-rich horizon in the Dopolan bauxite deposit.

Acknowledgments: All financial support for this research was provided by the Research Office at Shiraz University, Iran. Iranian Mines \& Mining Industries Development \& Renovation (IMIDRO) is greatly acknowledged for support of the ICP-MS and XRD analyses. The CEO of the Dopolan bauxite mine is thanked for providing unlimited access to the Dopolan deposits. The Enago group is thanked for their assistance in editing the English. We would like to give our sincere thanks to Maria Economou-Eliopoulos of the University of Athens for reviewing an earlier version of the manuscript and constructive comments. Special thanks are extended to two anonymous reviewers for their valuable and constructive comments on the manuscript.

Author Contributions: Salamab Ellahi, Taghipour, and Nejadhadad conceived and designed the experiments; Taghipour, contributed reagents/materials/analysis tools; Nejadhadad, Taghipour and Salamab Ellahi wrote the paper.

Conflicts of Interest: The authors declare no conflict of interest.

\section{References}

1. Ozturk, H.; Hein, R.J.; Hanilci, N. Genesis of the Dogфankuzu and Mortas, bauxite deposits, Taurides, Turkey: Separation of $\mathrm{Al}, \mathrm{Fe}$, and $\mathrm{Mn}$ and implications for passive margin metallogeny. Econ. Geol. 2002, 97, 1063-1077. [CrossRef]

2. Laskou, M.; Economou-Eliopoulos, M. Micro-organisms as fossils and present day development in Ni-laterites and bauxites of the Balkan Peninsula. In Mineral Deposits Research Meeting the Global Challenge, Proceedings of the Eighth Biennial SGA Meeting, Beijing, China, 18-21 August 2005; Mao, J., Bierlein, F.P., Eds.; Springer: Berlin/Heidelberg, Germany, 2005; pp. 1003-1006.

3. Laskou, M.; Economou-Eliopoulos, M. The role of microorganisms on the mineralogical and geochemical characteristics of the Parnassos-Ghiona bauxite deposits, Greece. J. Geochem. Explor. 2007, 93, 67-77. [CrossRef]

4. Laskou, M.; Economou-Eliopoulos, M. Bio-mineralization and potential biogeochemical processes in bauxite deposits: genetic and ore quality significance. Mineral. Petrol. 2012, 73, 124-140. [CrossRef]

5. Kalaitzidis, S.; Siavalas, G.; Skarpelis, N.; Carla Viviane Araujo, C.; Christanis, C. Late Cretaceous coal overlying karstic bauxite deposits in the Parnassus-Ghiona Unit, Central Greece: coal characteristics and depositional environment. Int. J. Coal Geol. 2010, 81, 211-226. [CrossRef]

6. Kalatha, S.; Economou-Eliopoulos, M. Framboidal pyrite and bacterio-morphic goethite at transitional zones between-Fe-Ni-laterite and limestones: Evidence from Lokris, Greece. Ore Geol. Rev. 2015, 65, 413-425. [CrossRef]

7. Lovely, D.R. Microbial reduction of iron, manganese, and other metals. Adv. Agron. 1995, 54, $175-231$.

8. Berthelin, J. Microbial weathering processes. In Microbial Geochemistry; Krumbein, W.E., Ed.; Blackwell Scientific Publications: Oxford, UK, 1983; pp. 223-263.

9. Furrer, G.; Stumn, W. A coordination chemical approach to the kinetics of weathering. I. Dissolution of $\delta-\mathrm{Al}_{2} \mathrm{O}_{3}$ and BeO. Geochim. Cosmochim. Acta 1986, 50, 1847-1860. [CrossRef]

10. McBride, M.; Sauvé, S.; Hendershot, W. Solubility control of $\mathrm{Cu}, \mathrm{Zn}, \mathrm{Cd}$ and $\mathrm{Pb}$ in contaminated soils. Eur. J. Soil Sci. 1997, 48, 337-346. [CrossRef]

11. Müller, B.; Axelesson, M.D.; Öhlander, B. Adsorption of trace elements on pyrite surfaces in sulfidic mine tailing from Kristenberg (Sweden) a few years after remediation. Sci. Total Environ. 2002, 298, 1-16. [CrossRef] 
12. Lazo, O.; Cullaj, A.; Deda, T. Arsenic in soil environments in Albania. In Arsenic in Soil and Groundwater: Biogeochemical Interactions; Bhattacharya, P., Mukherjee, A.B., Zevenhoven, R., Loeppert, R., Eds.; Elsevier Book Series; Elsevier: Amsterdam, The Netherlands, 2007.

13. Oliveira, F.S.; Varajao, A.F.D.; Varajao, C.A.C.; Schaefer, C.E.G.R.; Bolange, B. The role of biogical agents in the microstructural and mineralogical transformations in aluminium lateritic deposit in Central Brazil. Geoderma 2014, 226-227, 250-269. [CrossRef]

14. Liaghat, S.; Hossini, M.; Zarasvandi, A. Determination of the origin and mass change geochemistry during bauxitization process at the Hangam Deposit, SE Iran. Geochem. J. 2003, 37, 627-637. [CrossRef]

15. Zarasvandi, A.; Charchi, A.; Carranza, E.J.M.; Alizadeh, B. Karst bauxite deposits in the Zagros mountain belt, Iran. Ore Geol. Rev. 2008, 34, 521-532. [CrossRef]

16. Zarasvandi, A.; Carranza, E.J.M.; Ellahi, S.S. Geological, geochemical, and mineralogical characteristics of the Mandan and Deh-now bauxite deposits, Zagros Fold Belt, Iran. Ore Geol. Rev. 2012, 48, 125-138. [CrossRef]

17. Calagari, A.A.; Abedini, A. Geochemical investigations on Permo-Triassic bauxite horizon at Kanisheeteh, east of Bukan, West-Azarbaidjan, Iran. J. Geochem. Geoexplor. 2007, 93, 232-576. [CrossRef]

18. Salamab Ellahi, S.; Taghipour, B.; Zarasvandi, A.; Bird, M.I.; Somarin, A.K. Mineralogy, Geochemistry and Stable Isotope Studies of the Dopolan Bauxite Deposit, Zagros Mountain, Iran. Minerals 2016, 6, 11.

19. Ehsanbakhsh, M.H.; Rahimzadeh, F. Ardal Map 1; 100000; Geological Survey and Mineral Exploration: Tehran, Iran, 1996.

20. Takin, M. Iranian geology and continental drift in the Middle East. Nature 1972, 235, 147-150. [CrossRef]

21. Agard, P.; Omrani, J.; Jolivet, L.; Mouthereau, F. Convergence history across Zagros, Iran: Constraints from collisional and earlier deformation. Int. J. Earth Sci. 2005, 94, 401-419. [CrossRef]

22. Walkey, A.; Black, I.A. An examination of Degtjareff method for determining soil organic matter, and proposed modification of the chromic acid titration method. Soil Sci. 1934, 37, 29-38. [CrossRef]

23. Baskar, S.; Baskar, R.; Kaushik, A. Role of microorganisms in weathering of the Konkan-Goa laterite formation. Curr. Sci. 2003, 85, 1129-1134.

24. Spatio, G. The Geochemistry of Soil; Oxford University Press: New York, NY, USA, 1989; p. 27.

25. Chapelle, F.H. Ground-Water Microbiology and Geochemistry; John Wiley \& Sons: New York, NY, USA, 1993.

26. Berner, R.A. Biogeochemical cycles of carbon and sulfur and their effect on atmospheric oxygen over Phanerozoic time. Palaeogeogr. Palaeoclimatol. Palaeoecol. 1989, 75, 97-122. [CrossRef]

27. Jensen, M.L. Sulfur isotopes and mineral genesis. In Geochemistry of Hydrothermal Ore Deposits; Barnes, H.L., Ed.; Holt, Rinehart, and Winston: New York, NY, USA, 1967; pp. 143-165.

28. Ohmoto, H.; Rye, R.O. Isotopes of sulfur and carbon. In Geochemistry of Hydrothermal Ore Deposits; Barnes, H.L., Ed.; Wiley and Sons: New York, NY, USA, 1979; pp. 509-567.

29. Ohmoto, H.; Goldhaber, M.B. Sulfur and carbon isotopes. In Geochemistry of Hydrothermal Ore Deposits; Barnes, H.L., Ed.; Wiley and Sons: New York, NY, USA, 1997; pp. 517-611.

30. Seal, R. Sulfur Isotope Geochemistry of Sulfide Minerals; U.S. Geological Survey Staff-Published Research: Reston, VA, USA, 2006; p. 345.

31. Roedder, E. The noncolloidal origin of "colloform" textures in sphalerite ores. Econ. Geol. 1968, 63, 451-471. [CrossRef]

32. Anderson, G.M. The mixing hypothesis and the origin of Mississippi Valley-type ore deposits. GeoFluids 2008, 103, 1683-1690. [CrossRef]

33. Nejadhadad, M.; Taghipour, B.; Zarasvandi, A.K.; Somarin, A. Geological, geochemical, and fluid inclusion evidences for the origin of the Ravanj $\mathrm{Pb}-\mathrm{Ba}-\mathrm{Ag}$ deposit, north of Delijan city, Markazi Province, Iran. Turk. J. Earth Sci. 2016, 25, 179-200. [CrossRef]

34. Wang, H.; Morse, H.C. IRF8 regulates myeloid and B lymphoid lineage diversification. Immunol. Res. 2009, 43, 109-117. [CrossRef] [PubMed]

35. Patterson, S.H. Bauxite Reserves and Potential Aluminum Resources of the World; U.S. Geological Survey: Reston, VA, USA, 1967; pp. 1228-1258.

36. Brimhall, G.H.; Lewis, C.J.; Ague, J.J.; Dietrich, W.E.; Hampel, J.; Teague, T.; Rix, P. Metal enrichment in bauxites by deposition of chemically-mature aeolian dust. Nature 1988, 333, 819-824. [CrossRef]

37. Ehrlich, H.L.; Wickert, L.M.; Noteboom, D.; Doucet, J. Weathering Pisolitic Bauxite by Heterotrophic Bacteria; University of Chile: Santiago, Chile, 1995; Volume I, pp. 395-403.

38. McLean, E.D. Chemistry of soil aluminum. Commun. Soil Sci. Plant Anal. 1976, 7, 619-636. [CrossRef] 
39. Thomas, G.W. Soil pH and Soil Acidity. In Methods of Soil Analysis: Chemical Methods; Soil Sciences Society of America/American Society of Agronomy: Madison, WI, USA, 1996; Part 3; pp. 475-496.

40. Liu, X.; Wang, Q.; Feng, Y.; Cai, Z. Genesis of the Guangou karstic bauxite deposit in western Henan, China. Ore Geol. Rev. 2013, 55, 162-175. [CrossRef]

41. Zhang, Z.; Zhou, L.; Li, Y.; Wu, C.; Zheng, C. The "coal-bauxite iron" structure in the ore-bearing rock series as a prospecting indicator for southeastern Guizhou bauxite mines. Ore Geol. Rev. 2013, 53, 145-158. [CrossRef]

42. Buchanan, S.J.; So, H.B.; Kopittk, P.M.; Menzies, N.W. Influence of texture in bauxite residues on void ratio, water holding characteristics, and penetration resistance. Geoderma 2010, 158, 421-426. [CrossRef]

43. Garrels, R.; Christ, L.C. Solutions, Minerals, and Equilibria; John Wiley: New York, NY, USA, 1965; 450p.

44. Maksimovic, Z.; Panto, G. Contribution to the geochemistry, of rare earth elements in the karst-bauxite deposits of Yugoslavia and Greece. Geoderma 1991, 51, 93-109. [CrossRef]

45. Carrillo-González, R.; González-Chávez, M. Metal accumulation in wild plants surrounding mining wastings. Environ. Pollut. 2006, 144, 84-92. [CrossRef] [PubMed]

46. Meshram, R.R.; Randiv, K.R. Geochemical study of laterites of the Jamnagar district, Gujarat, India: implications on parent rock, mineralogy and tectonics. J. Asian Earth Sci. 2011, 42, 1271-1287. [CrossRef]

47. Mordberg, L.E.; Spratt, J. Alteration of zircons: The evidence of Zr mobility during bauxitic weathering. In Proceedings of the Goldschmidt Conference Toulouse, Toulouse, France, 30 August-3 September 1998; pp. 1021-1022.

48. Hill, I.G.; Worden, R.H.; Meighan, I.G. Geochemical evolution of a palaeolaterite: The Interbasaltic Formation, Northern Ireland. Chem. Geol. 2000, 166, 65-84. [CrossRef]

49. Karadag, M.M.; Kupeli, S.; Aryk, F.; Ayhan, A.; Zedef, V.; Doyen, A. Rare earth element (REE) geochemistry and genetic implications of the Mortas bauxite deposit (Seydisehir/Konya-Southern Turkey). Chemie der Erde 2009, 69, 143-159. [CrossRef]

50. Laufer, F.; Yariv, S.; Steinberg, M. The adsorption of quadrivalent cerium by kaolinite. Clay Miner. 1984, 19, 137-149. [CrossRef]

51. Mongelli, G. Ce-anomalies in the textural components of Upper Cretaceous karst bauxites from the Apulian carbonate platform (southern Italy). Chem. Geol. 1997, 14, 69-79. [CrossRef]

52. Roaldest, E. Mineralogical and Chemical Changes during Weathering, Transportation and Sedimentation in Different Environments. Ph.D. Thesis, University of Oslo, Oslo, Norway, 1978.

53. Forstner, U. Metal speciation-general concepts and applications. Int. J. Environ. Anal. Geochem. 1993, 51, 5-23. [CrossRef]

54. Kersten, M.; Forstner, U. Geochemical characterization of the potential trace metal mobility in cohesive sediments. Geo-Mar. Lett. 1991, 11, 184-187. [CrossRef]

55. Nealson, K.H.; Stahl, D.A. Microorganisms and biogeochemical cycles: What can we learn from layered microbial communities. Rev. Mineral. 1997, 35, 5-34.

56. Ehrlich, H.J. Geomicrobiology, 4th ed.; Marcel Dekker: New York, NY, USA, 2002; p. 800.

57. Strauss, H.; Scchieber, J. A sulfur isotope study of pyrite genesis: The Mid-Protezoic Newland Formation, Belt supergroupe, Montana. Geochim. Cosmochim. Acta 1990, 54, 197-204. [CrossRef]

58. Goldhaber, M.B. Sulfur-Rich Sediments. Treatise on Geochemistry: Sediments, Diagenesis, and Sedimentary Rocks; Elsevier: Amsterdam, The Netherlands, 2003; Volume 7, pp. 257-288.

59. Hoefs, J. Stable Isotope Geochemistry, 6th ed.; Springer: Berlin, Germany, 2009; p. 285.

60. Smock, A.M.; Bottcher, M.E.; Cypionka, H. Fractionation of sulfur isotopes during thiosulfate reduction by Desulfovibrio desulfuricans. Arch. Microbiol. 1998, 169, 460-463. [CrossRef] [PubMed]

61. Smith, D.W.; Rittenberg, S.C. On the sulfur-source requirement for growth of Thiobacillus intermedius. Arch. Microbiol. 1974, 100, 65-71. [CrossRef] [PubMed]

(C) 2017 by the authors. Licensee MDPI, Basel, Switzerland. This article is an open access article distributed under the terms and conditions of the Creative Commons Attribution (CC BY) license (http:/ / creativecommons.org/licenses/by/4.0/). 